\title{
IMPORTATION TO NEW ZEALAND QUARANTINE OF A CANDIDATE BIOLOGICAL CONTROL AGENT OF CLOVER ROOT WEEVIL
}

\author{
S.L. GOLDSON, C.B. PHILLIPS, M.R. McNEILL, J.R. PROFFITT and \\ R.P. CANE \\ AgResearch Limited, Biocontrol and Biosecurity Group, PO Box 60, Lincoln, \\ Canterbury, New Zealand \\ Corresponding author: stephen.goldson@agresearch.co.nz
}

\begin{abstract}
Several candidate biological control agents of Sitona lepidus have been identified since a search commenced in 1997. Interestingly, Microctonus aethiopoides from Europe is a much more effective parasitoid of S. lepidus than the M. aethiopoides ecotype already established in New Zealand. To assess further the suitability of the European M. aethiopoides for biological control of S. lepidus, 1599 infected S. lepidus were shipped to New Zealand quarantine during late 2000. These yielded 267 parasitoid pupae from which 204 adult parasitoids were reared. This material was obtained from a wide geographical range in Europe and has been used to establish cultures in New Zealand quarantine based on genetic material from France, England, Norway, Finland, Romania, Ireland, Scotland, Italy and Wales. This contribution presents an overview of the work associated with the importation of the parasitoids and the effort now being made to maintain genetic diversity. Planned research is also discussed.

Keywords: clover root weevil, biological control, Microctonus aethiopoides, Sitona lepidus, Trifolium repens.
\end{abstract}

\section{INTRODUCTION}

Sitona lepidus was first recorded in Waikato, New Zealand, in March 1996 (Barratt et al. 1996) and has since spread at ca $35 \mathrm{~km} /$ year (Willoughby \& Addison 1997a). Surveys have revealed extremely high densities both of adult weevils feeding on white clover foliage and of larvae on plant rhizobial nodules and roots. The associated reduction in plant vigour and nitrogen fixation has resulted in S. lepidus becoming recognised as a serious threat to New Zealand's competitive edge in pastoral production (Willoughby \& Addison 1997b). In the last 20 years, the lucerne weevil Sitona discoideus and the Argentine stem weevil Listronotus bonariensis have been usefully suppressed by introductions of $M$. aethiopoides and Microctonus hyperodae respectively (Goldson et al. 1990; Goldson et al. 1998). Thus, an early response to the discovery of S. lepidus was to test whether either of these parasitoids would be useful against it. However, neither showed any potential for control of the weevil (Barratt et al. 1997).

A range of initiatives has been established to attempt to offset the threat posed by S. lepidus. One of these has been the implementation of a comprehensive effort to find suitable biological control agents. Preliminary work and searches conducted in 1998 and 1999 indicated that such agents are most likely to be found in Europe (Phillips et al. 2000; Goldson et al. 2001a). In the European summer of 2000, a major effort was made to identify and collect the most promising $S$. lepidus natural enemies from a wide range of locations. As it happened, $M$. aethiopoides was consistently found to be the best option (Goldson et al. 2001b; C.B. Phillips, unpubl. data) in spite of the converse observation of Barratt et al. (1997) that the New Zealand ecotype was ineffective. Indeed, 
this difference has highlighted the importance of thoroughly exploring intraspecific variation in biological control agents (Goldson et al. 1997).

This work resulted in ca 8500 S. lepidus being collected from 15 locations in 11 European countries. The parasitoids were reared out and identified, initially by AgResearch staff based at the USDA's European Biological Control Laboratory in Montpellier, France, and later at the Institute of Grassland and Environmental Research at North Wyke, Devon. All ecotypes of M. aethiopoides were found to develop readily in both British and New Zealand populations of S. lepidus (Goldson et al. 2001b; C.B. Phillips, unpubl. data).

Given the promising performance of $M$. aethiopoides collected in Europe, populations were shipped from North Wyke to New Zealand containment for culturing and analysis. This contribution reports on the forwarding of such material to New Zealand, how its genetic diversity is being maintained and the way in which it is being evaluated as a S. lepidus biological control agent.

\section{METHODS AND MATERIALS}

\section{Shipments}

Shipment of weevils within Europe was by post, using supplied pre-addressed 'bubble' envelopes and $60 \mathrm{~mm} \times 20 \mathrm{~mm}$ vials with gauze tops into which the weevils were placed.

Four consignments of live parasitised weevils were forwarded to New Zealand by airfreight. Because the freight-forwarding companies were reluctant to transport 'live animals', it was easier to send the material directly using separate airway bills, thereby avoiding the use of the freight-forwarding companies. Effectively, this was via direct negotiation with Air New Zealand.

Each of the four shipments from North Wyke comprised up to eight $60 \mathrm{~mm} \times 20 \mathrm{~mm}$ vials each containing up to 100 weevils along with a $40 \mathrm{~mm} \times 50 \mathrm{~mm}$ corrugated cardboard strip and 4-5 trifoliate leaves of white clover. These vials were then packed into $244 \mathrm{~mm}$ x $196 \mathrm{~mm}$ x $106 \mathrm{~mm}$ (depth) polystyrene boxes with damp tissue placed on top. Each box was then securely taped before being sealed inside a pre-addressed and suitably labelled cardboard box.

Containment facilities

M. aethiopoides populations were transported to New Zealand as larvae in British and/or New Zealand S. lepidus. Given that a CSIRO-sourced population of M. aethiopoides was introduced into New Zealand in 1982 (Stufkens et al. 1987), the New Zealand Ministry of Agriculture and Forestry Quarantine Service was able to give permission for the additional live, conspecific material to be maintained in New Zealand containment facilities. Initially, the material which consisted of parasitised weevils from both Europe and New Zealand was imported to the Landcare Research transitional and containment facility at Lincoln. Here the parasitoids were reared to the adult stage whereafter they were used to infect Waikato-collected S. lepidus. After obtaining permission from MAF Quarantine, the parasitoid cultures were transferred to an AgResearch containment facility. Full attention to security has been maintained throughout as S. lepidus has yet to be found in Canterbury and any escapes could result in establishment of the weevil in the Lincoln district.

\section{Maintenance of $M$. aethiopoides cultures and their genetic diversity}

The primary aims of ensuing work in containment at Lincoln are to maintain each geographic population separately and to minimise losses of genetic diversity. This has demanded the ongoing development of a systematic rearing system specifically designed to minimise inbreeding, selection for laboratory fitness, and inadvertent loss of genetic diversity through extinction. Initially, depending on availability, up to four male/female pairs of $M$. aethiopoides from each geographical location were used to establish each population in culture. Thereafter, sibling mating was avoided whenever possible by allowing female parasitoids to mate only with males from another pair within their 'ecotype' (or 'hybrid') group.

Broadly, the method of rearing M. aethiopoides on S. lepidus is similar to that described for rearing M. aethiopoides on S. discoideus (Goldson et al. 1990). Newly-emerged 
( $<24 \mathrm{~h}$ ) female $M$. aethiopoides parasitoids are mated with single males in $60 \mathrm{~mm}$ diameter vials. The mated females are then individually confined for $48-72 \mathrm{~h}$ at $20^{\circ} \mathrm{C}$ in $220 \mathrm{~mm}$ x $130 \mathrm{~mm}$ x $75 \mathrm{~mm}$ cages with 40-60 Waikato-collected S. lepidus. The parasitoids are also provided with $5 \mathrm{~mm}$ squares of filter paper soaked in honey solution along with two or three white clover plants grown in $60 \mathrm{~mm}$ x $25 \mathrm{~mm}$ diameter soil plugs and sealed in $50 \mathrm{~mm} \times 100 \mathrm{~mm}$ polythene bags. After removal of the parasitoid, the weevils are maintained for ca 3 weeks at $20^{\circ} \mathrm{C}$. Their cages are fitted with a $0.5 \mathrm{~mm}$ gauze floor and positioned over a lower chamber into which are placed strips of paper towel. This allows the emergent prepupal parasitoids to drop through the gauze floor and pupate in the paper strips. The pupae are then transferred to $90 \mathrm{~mm}$ diameter Petri dishes along with a moistened dental wick until adult eclosion. Petri dishes are checked daily for newly-emerged parasitoids to reduce the possibility of sibling mating.

All biological material has been preserved either in alcohol or at $-40^{\circ} \mathrm{C}$ for further research.

\section{RESULTS AND DISCUSSION}

The details relating to the material shipped to New Zealand are summarised in Table 1. The mean mortality level across these shipments was $19 \%$ and reflected the difficulty encountered in transporting live material from Europe to New Zealand. Nonetheless, by November 2000, six 'ecotypes' of $M$. aethiopoides had been established in containment at Lincoln. These were from Aberystwyth (Wales), Athenry (Ireland), Heggenes (Norway), Mikkeli (Finland), Montpellier (France) and North Wyke (England). In addition, 'hybrids' were established from North Wyke/Brasov (Romania), Mikkeli/ Pordenone (Italy), Mikkeli/Wigtown (Scotland) and Montpellier/Nancy (France) (Fig. 1). The mean level of parasitism of S. lepidus by M. aethiopoides in the field in Europe, as determined by maintaining weevils in cages and monitoring the emergence of parasitoid pupae, was ca $2 \%$. The higher levels of parasitism $(12 \%-29 \%)$ suggested by the data in Table 1 occurred because most $M$. aethiopoides populations were reared for at least one generation in the laboratory at North Wyke before being imported to New Zealand quarantine.

TABLE 1: Details of shipments of Microctonus aethiopoides forwarded from North Wyke to containment facilities at Lincoln, New Zealand.

\begin{tabular}{lcccc}
\hline $\begin{array}{l}\text { Date received in } \\
\text { New Zealand }\end{array}$ & $\begin{array}{c}\text { Total number } \\
\text { of weevils }\end{array}$ & $\begin{array}{c}\text { Percent } \\
\text { mortality }\end{array}$ & $\begin{array}{c}\text { Total parasitoid } \\
\text { pupae }\end{array}$ & $\begin{array}{c}\text { Total parasitoid adults } \\
\text { reared out from pupae }\end{array}$ \\
\hline 19 September 2000 & 249 & 15 & 73 & 58 \\
25 September 2000 & 637 & 13 & 105 & 87 \\
21 October 2000 & 403 & 31 & 53 & 39 \\
11 November 2000 & 310 & 14 & 36 & 20 \\
Total & 1599 & & 267 & 204 \\
\hline
\end{tabular}

Ongoing maintenance of genetic diversity within the cultured populations has proved challenging due to: a) unpredictable and occasionally very low numbers of parasitoid progeny arising from exposures of parasitoids to $S$. lepidus in cages; b) highly variable sex ratios of the parasitoid progeny; c) difficulties in ensuring that female parasitoids are mated; and d) sporadic troubles obtaining sufficient S. lepidus from Waikato during wet weather when collecting is not possible. Due to these problems, bottlenecks have occurred in the culture. By May 2001, each population could be traced back to the following numbers of parental pairs: Aberystwyth (Wales) 2; Athenry (Ireland) 1, Heggenes (Norway) 3, Mikkeli (Finland) 1, Montpellier (France) 2, North Wyke (England) 3, North Wyke/Brasov (Romania) 2, Mikkeli/ Pordenone (Italy) 2, Mikkeli/Wigtown (Scotland) 1, and Montpellier/Nancy (France) 3. 
Refinements to the culturing methods are aimed at reducing the risk of losing further genetic stock. The culture is currently being used to provide material for analysis of the ecotypic variation of European populations of $M$. aethiopoides as it relates to their potential to act as control agents for S. lepidus. This includes investigation of fecundity, longevity, mating behaviour, attack rates, development rates, host range testing and, tolerance to $S$. lepidus immune responses. DNA-based investigation into the genetic structure of the European and New Zealand populations of M. aethiopoides and S. lepidus has also commenced.

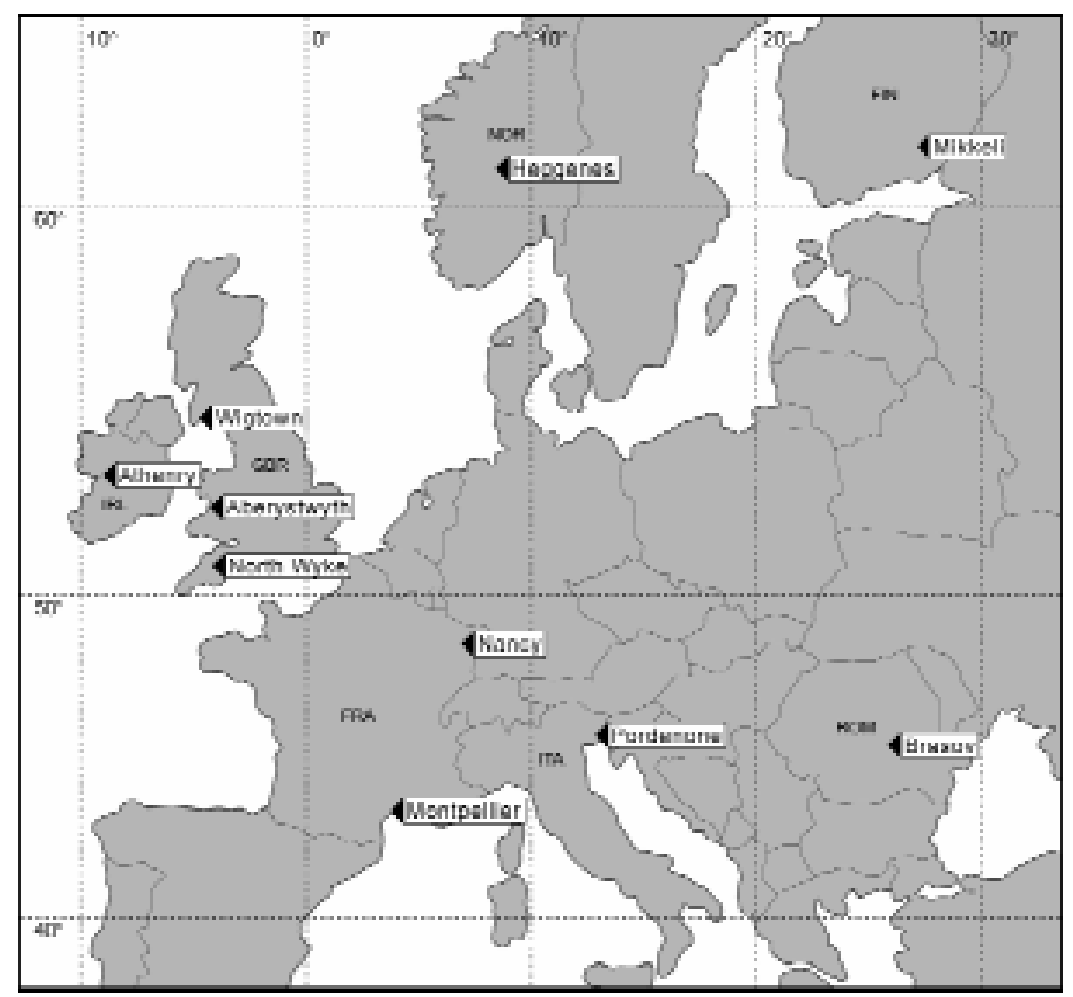

FIGURE 1: Collection sites of Microctonus aethiopoides populations that were put into New Zealand quarantine between September and November 2000.

\section{ACKNOWLEDGEMENTS}

The authors gratefully acknowledge the contributions made at North Wyke by Pip Gerard (AgResearch Ruakura) and Chris Galbraith (AgResearch Lincoln). Scott Hardwick, Birgitta Harens, Derrick Wilson, Fiona Kettlewell, Tina Eden and Bruce Willoughby from AgResearch, Ruakura, generously provided live S. lepidus for experiments in Montpellier and North Wyke, as well as for maintaining the M. aethiopoides culture at Lincoln. Simon Kelly, AgResearch, Lincoln, provided expert help in maintaining the parasitoid culture. The collection of M. aethiopoides from a wide range of European locations was achieved through the invaluable assistance of IGER at North Wyke, the USDA (EBCL) at Montpellier, and COST collaborators throughout Europe. Funding 
was gratefully obtained from diverse sources including the Foundation for Research, Science and Technology, the Combined Pastoral Producer Boards, the Lincoln University Foundation, AGMARDT, the C. Alma Baker Trust and NZ Grasslands Association.

\section{REFERENCES}

Barratt, B.I.P.; Barker, G.M.; Addison, P.J. 1996: Sitona lepidus (Coleoptera: Curculionidae), a potential clover pest new to New Zealand. N.Z. Entomol. 19: 2330.

Barratt, B.I.P.; Evans, A.A.; Ferguson, C.M. 1997: Potential for biocontrol of Sitona lepidus by Microctonus spp. Proc. 50th N.Z. Plant Prot. Conf.: 37-40.

Goldson, S.L.; McNeill, M.R.; Gerard, P.J.; Proffitt, J.R.; Phillips, C.B.; Cane, R.P.; Murray, P.J. 2001b: British-based search for natural enemies of the clover root weevil, Sitona lepidus in Northwest Europe. Bull. Entomol. Res. (submitted).

Goldson, S.L.; McNeill, M.R.; Phillips, C.B.; Proffitt, J.R. 2000: COST 814; Biocontrol Links to New Zealand. In: Parente, G.; Frame, J. ed. European Commission Cost Action 814. Crop development for the cool and wet regions of Europe, Proceedings of the final conference, Pordenone, Italy, 10-13 May, 2000. Pp. 291-297.

Goldson, S.L.; Phillips, C.B.; McNeill, M.R.; Barlow, N.D. 1997: The potential of parasitoid strains in biological control: observations to date on Microctonus spp. intraspecific variation in New Zealand. Agric. Ecosystems Environ. 64: 115-124.

Goldson, S.L.; Proffitt, J.R.; Baird, D.B. 1998: Establishment and phenology of the parasitoid Microctonus hyperodae Loan in New Zealand. Environ. Entomol. 27: 1386-1392.

Goldson, S.L.; Proffitt, J.R.; McNeill, M.R. 1990: Seasonal biology and ecology in New Zealand of Microctonus aethiopoides (Hymenoptera: Braconidae), a parasitoid of Sitona spp. (Coleoptera: Curculionidae), with special emphasis on atypical behaviour. J. Appl. Ecol. 27: 703-722.

Phillips, C.B.; Goldson, S.L.; Reimer, L.; Kuhlmann, U. 2000: Progress in the search for biological control agents of the clover root weevil, Sitona lepidus (Coleoptera: Curculionidae). N.Z. J. Agric. Res. 43: 541-547.

Stufkens, M.W.; Farrell, J.A.; Goldson, S.L. 1987: Establishment of Microctonus aethiopoides, a parasitoid of the sitona weevil in New Zealand. Proc. 40th N.Z. Weed and Pest Control Conf: : 31-32.

Willoughby, B.; Addison, P. 1997a: Clover root weevil (Sitona lepidus) - a threat to sustainability of white clover in New Zealand pastures? Proc. N.Z. Grassland Assoc. 59: 23-27.

Willoughby, B.; Addison, P. 1997b: Assessment of the dispersal of Sitona lepidus (clover root weevil) in the North Island of New Zealand. Proc. 50th N.Z. Plant Prot. Conf.: 33-36. 